\title{
The contribution of Learning and Environmental Discipline on Students 'Learning Outcomes in The Housekeeping Class X Class in SMK 1 Bintan
}

\author{
Siti Zam Zainah ${ }^{1}$, Ganefri $^{2}$, Nurhasan Syah ${ }^{3}$, Vina N.Van Harling ${ }^{4}$, Agus Sutanto ${ }^{5}$, B. \\ Herawan Hayadi ${ }^{6}$ \\ Master of Technology and Vocational Education Masters Program, Faculty of Engineering, \\ Padang State University, Padang, Indonesia ${ }^{1,2,3}$ \\ Politeknik Katolik Saint Paul, Sorong Indonesia ${ }^{4}$ \\ Universitas Muhammadiyah Metro. Lampung Indonesia ${ }^{5}$ \\ University of Pasir Pengaraian, Riau Indonesia ${ }^{6}$ \\ \{sitizam.zainah@gmail.com $\left.{ }^{1}\right\}$
}

\begin{abstract}
Based on the results of the initial observation made to at SMKN 1 Bintan, there were several problems faced by the school. The problem that often occurs is that students are often late in class and rarely make assignments given by teachers in schools so that the learning outcomes of students become low. Based on this problem, the researcher is interested in researching to see whether there are a disciplinary contribution and learning environments to students' learning outcome in housekeeping subjects at SMKN 1 Bintan. In this study, researchers used a type of correlational research. This research was a contribution to learning outcomes, the contribution of learning discipline and the learning environment jointly to learning the outcome, as well as to find out the magnitude of the direction of the magnitude or the direction of the relationship. The method used is correlational quantitative research (correlation research). So that this study aims to investigate the correlation or influence of learning discipline and learning discipline and learning environment on learning achievement based on the correlation coefficient. The results obtained from this study can be concluded that the discipline of learning contribution to student learning contributes to by $22,6 \%$, the learning environment contributes to learning outcome by $46,4 \%$, learning environment together contributes $52,6 \%$. This means, the higher the discipline of learning and the better the learning environment, the learning outcome of Housekeeping subject will increase. The recommendation of this research for schools in need of efforts to improve the learning environment in Housekeeping subjects at SMKN 1 Bintan.
\end{abstract}

Keywords: SMKN 1 Bintan, Disciplinary, correlation research 


\section{Introduction}

Education is something very necessary for all aspects of life [1]. Learning activities are activities that must be carried out by each student for the education process in the school. Success or failure of education goals depends on how the process is carried out by students in taking education itself. To support high discipline and a good learning environment, educators should provide instruction or guidance regarding behavior, politeness, and intelligence of the mind. According to Wiyani [2] the teacher must create a learning condition that is the best for the students, this is classified as the category of the teacher's role as the teacher, the teacher also acts as a guide and it is not impossible that the teacher is a substitute for parents, which means ready to give assistance to each to achieve maximum understanding and adaptation to the scope of the school. Discipline based on the norms or values that have been owned, both in the family environment and in the wider environment, must be able to be developed through transformation and adaptation of values to form a discipline to create a developed society[3], [4].

Being rational able to be independent, having a broad view of appreciating the time to realize the importance of planning and orienting far ahead prioritizing results, realizing the importance of specialization, optimizing the benefits of communication and information tools and demanding legal certainty and order are the characteristics of advanced societies[5]. From the results of temporary observations that the author did at SMK 1 Bintan, students were often late in class, and rarely made assignments given by the teacher at school. By giving assignments and assignments on an ongoing basis that make students bored, solutions always take sides with the teacher. Discipline applied by educators to students is measured by changes in attitudes of students, from the less disciplined to good behavior and discipline, confidence and independence. In this case, it means that with the motivations of students in the discipline, each student can improve learning outcomes, and cause students to study diligently, which of course will encourage better learning outcomes.

The author has observed directly and saw that the lack of awareness of students towards the discipline of learning. This is seen from the learning outcomes of students who have not been optimal. There are still students who score below the minimum completeness criteria (KKM) set by the school for tourism expertise programs, which is 75 . This is indicated by a lack of discipline in learning and the learning environment of Grade X students in tourism expertise programs. The percentage of students who complete less when compared with students who have not been completed. Of the 37 AH1 hotel skills program students on housekeeping subjects only 19 people reached the KKM score, and 18 people had not yet reached the KKM score, and in the AH2 class of 37 students only 20 had achieved the KKM score, and 17 people had not yet reached the KKM score. Average values in AH1 72.14 and AH2 Classes 67.72. From these data, it can be concluded that the learning outcomes of students in each of the subjects are not optimal[6], [7].

One of the problems that often occurs is that students commit violations of discipline, by not obeying the rules at school, often being late to class, rarely doing assignments given by the teacher and some even lazy to take part in learning in class. For example, if the teacher has entered the classroom, students are still late in class, and often do not pay attention when the teacher explains the lesson in class. Then students often do not make assignments given by the teacher, for reasons of forgetting and being left behind[8]. One of the underlying, student learning discipline is the emergence of awareness of students to want to implement, obey the rules and make the tasks given by the teacher well by their respective responsibilities. During the learning process, there were still many students sitting in the school canteen, and strangely 
enough, the canteen owner let the students hide in the cafeteria. Then to get good learning outcomes, it also needs a good learning environment. During the learning process students need a comfortable, calm environment, and of course, they must support teaching and learning. An unfavorable environment will disrupt the teaching and learning process, so students will be hampered in absorbing lessons[9]. Then in the hospitality study program, there are still learning outcomes of students. If the quality of the school environment where many students succeed, of course, it will also give influence to all students to learn well and truly to compete for results, but vice versa if the learning environment is not conducive and mutually supportive, the learning outcomes will not be achieved according to what is desired. Based on the background of the problem, the authors are interested in researching "Contributions of Learning Discipline and Learning Environment Against Learning Outcomes in Housekeeping Subjects at SMK Negeri 1 Bintan."

The research design is a procedure or flow of research activities to be carried out by the author[10]. The instrument used for learning discipline and learning environment is a questionnaire (questionnaire) while on learning outcomes based on school archives documentation is the reported value of students. After the instrument is implemented than an analysis of the data obtained is used to determine the contribution of each variable, discipline contribution to learning outcomes, the learning environment contribution to learning outcomes, and the contribution of learning discipline and learning environment together towards learning outcomes. So that at the end of the study a conclusion can be drawn on what has been studied[11].

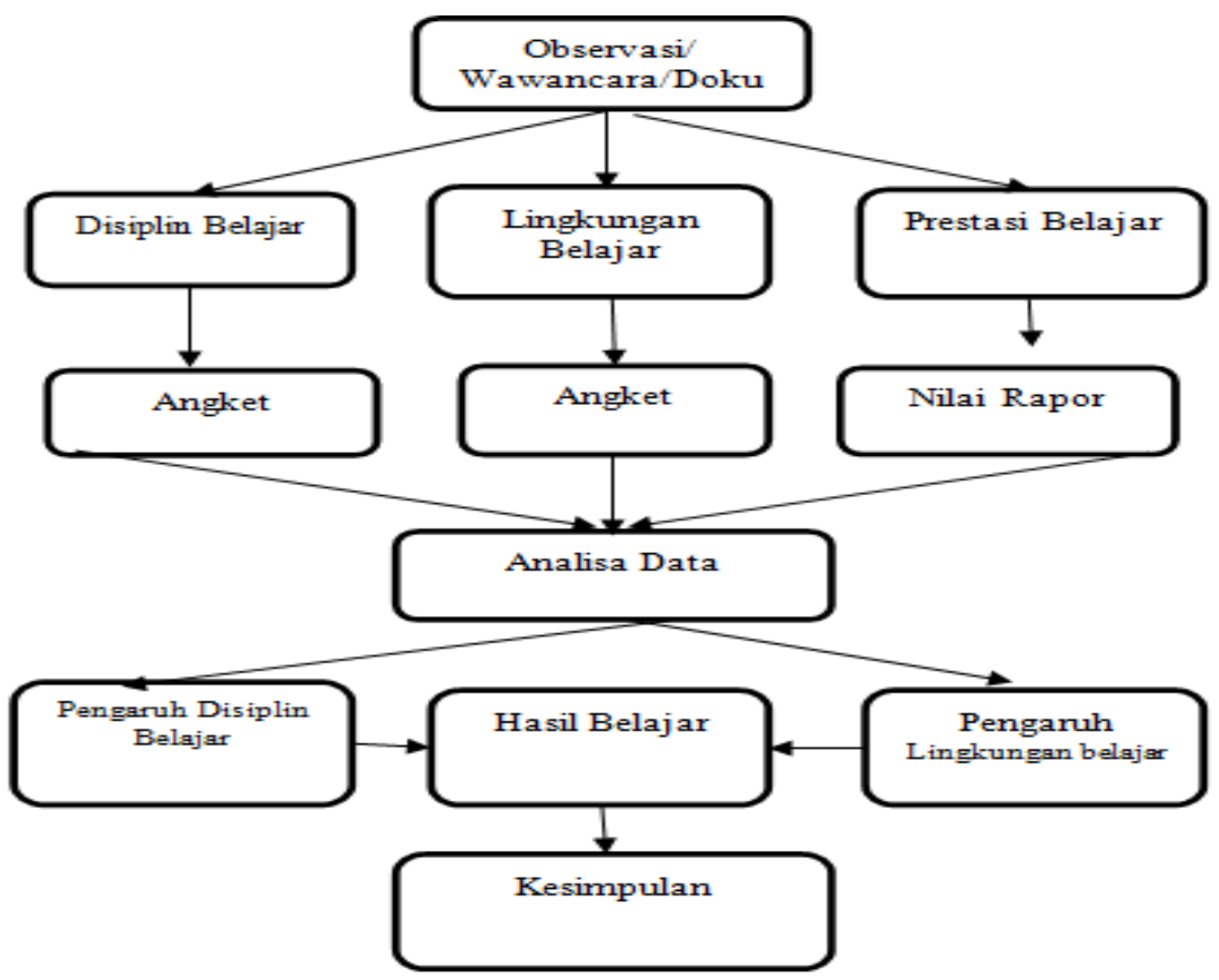


Figure 1. Research Design

\section{Population and samples}

\subsection{Population}

The population of this study was all students of class $\mathrm{X}$ majoring in hospitality at SMK Negeri 1 Bintan in the 2017/2018 school year which amounted to AH X1 37 people, and AH2 X 37 people.

Table 1. Total Population of State Vocational School 1 Bintan Hospitality Department. No Class Number of students

\subsection{Samples}

\begin{tabular}{lll}
\hline No & Class & Students \\
\hline 1. & X AH 1 & 37 \\
\hline 2. & X AH 2 & 37 \\
\hline & Total & 74 \\
\hline
\end{tabular}

Samples are part of the number and characteristics possessed by the population. Thus the sample is a portion of the population whose characteristics are to be investigated and can represent the entire population so that the number is less than the population. Sampling in this study uses Proportional Random Sampling techniques. Sampling using the Taro Yamane formula. The reason the researchers used the Taro Yamane formula was that the population in this study was less than 500 people and the population in this study was also known in number. The mathematical formulation of Taro Yamane, namely:

Information:

$\mathrm{n}=$ Number of samples

$\mathrm{N}=$ Total population

$\mathrm{d}=$ Percentage of inaccuracy due to sampling

which is not tolerated $(10 \%)$

$\mathrm{n}=74 /(1+74 . \llbracket(0.1) \rrbracket \wedge 2)=42.52=43$

Based on the results of the calculation of the Taro Yamane formula, the number of study samples obtained was 43 people.

\section{Result and discussion}

\subsection{Learning Discipline (X1)}

Learning discipline data was collected through a questionnaire consisting of 27 items that had been tested for validity and reliability. Then the questionnaire was given to 43 respondents to be filled. The following are basic statistical calculations of the disciplinary variables of learning.

Table 2. Results of Calculation of Learning Discipline Statistics

\begin{tabular}{ll}
\hline N Valid & 43 \\
\hline
\end{tabular}




\begin{tabular}{lr}
\hline Missing & 0 \\
\hline Mean & 72,56 \\
\hline Median & 74,100 \\
\hline Mode & 80 \\
\hline Std. Deviation & 9,35 \\
\hline Variance & 87,44 \\
\hline Range & 46 \\
\hline Minimum & 45 \\
\hline Maximum & 91 \\
\hline Sum & 3120 \\
\hline
\end{tabular}

Based on table 11 above, it can be seen that the learning discipline has a total data $(\mathrm{N})$ of 43 , mean 72.56 , median 74,100 , mode 80 , standard deviation of 9,35 , variance 87,42 , range 46 , minimum value 45 , the maximum value is 91 , and the total score is 3120 . The distribution of learning discipline scores can be seen in table 12 below.

Table 3. Distribution of Frequency of Learning Discipline Score Frequency Interval Number

\begin{tabular}{ccc}
\hline Nomor & Interval & Frekuensi \\
\hline 1 & $45-51$ & 1 \\
\hline 2 & $52-58$ & 2 \\
\hline 3 & $59-65$ & 6 \\
\hline 4 & $66-72$ & 10 \\
\hline 5 & $73-79$ & 13 \\
\hline 6 & $80-86$ & 9 \\
\hline 7 & $87-93$ & 1 \\
\hline 8 & $94-100$ & 1 \\
\hline \multicolumn{3}{c}{ Jumlah } \\
\hline
\end{tabular}

\subsection{Learning Environment (X2)}

Data variable learning environment uses a questionnaire consisting of 30 items that have been filled with validity and reliability. The next questionnaire was given to 43 respondents to be filled. The following are the basic statistics of the learning variables.

Table 4. Results calculated Learning Environment Statistics

\begin{tabular}{|c|c|c|}
\hline Nomor & Interval & Frekuensi \\
\hline 1 & $45-51$ & 1 \\
\hline 2 & $52-58$ & 2 \\
\hline 3 & $59-65$ & 6 \\
\hline 4 & $66-72$ & 10 \\
\hline 5 & $73-79$ & 13 \\
\hline 6 & $80-86$ & 9 \\
\hline 7 & $87-93$ & 1 \\
\hline 8 & $94-100$ & 1 \\
\hline \multicolumn{2}{|c|}{ Jumlah } \\
\hline
\end{tabular}


This study revealed that from 74 students who were sampled in this study by answering 27 items in order to reveal the magnitude of the discipline of learning contributions to learning outcomes, and 30 items to express the magnitude of the contribution of the learning environment to learning outcomes, and also reveal the magnitude of the learning discipline contribution and the learning environment together on learning outcomes

Learning discipline contributes to learning outcomes by $22.6 \%$, the learning environment contributes to learning outcomes by $46.4 \%$ and the disciplinary variables of learning and the learning environment together contribute to learning outcomes by $52.4 \%$.

\section{Conclusion and suggestion}

\subsection{Conclusion}

Based on the results of the research that has been done, conclusions can be taken as follows:

a. Learning discipline contributes to the results of students on Housekeeping subjects at SMK Negeri 1 Bintan. Contributions were given at $22.6 \%$. That is, the higher the learning discipline of students, the higher the learning outcomes in Housekeeping subjects.

b. The Learning Environment contributes to the learning outcomes of Housekeeping subjects at SMK Negeri 1 Bintan. Contributions given are $46.4 \%$. That is, the better the learning environment, the learning outcomes of Housekeeping subjects will increase.

c. The discipline of learning and the learning environment together contribute to the learning outcomes of Housekeeping subjects at SMK Negeri 1 Bintan by contributing $52.6 \%$. This means, the higher the discipline of learning and the better the learning environment, the learning outcomes of Housekeeping subjects will increase.

This research is only a preliminary study that has not been conclusive in providing complete problem solving, but at least it can be suggested

\subsection{Implication}

Based on the conclusions of the research above, the research implications can be made. It is necessary to strive to improve student learning discipline and the learning environment to improve learning outcomes in Housekeeping subjects. The implications of this study are as follows:

1. In the learning process, housekeeping participants are given the basics of skills that are beneficial to their lives. The results of this study reveal that the learning discipline of students is still in the low category, this indicates that there is still a lack of efforts by teachers and schools to improve the discipline of students learning to result in low learning outcomes of students on housekeeping subjects. So from that schools and teachers play an active role in improving students' learning discipline. Increased learning discipline of students will greatly help students in improving their learning outcomes, especially learning outcomes on housekeeping subjects.

2. A conducive learning environment will trigger a pleasant learning atmosphere, discipline, a sense of responsibility, rational thinking, motivating, solving problems rationally and increasing graduate competency. The results of this study reveal that the learning environment is still not good, will result in low learning outcomes of students on 
housekeeping subjects. For this reason, school is the party most responsible for providing the learning environment needs to students.

\subsection{Suggestion}

Based on the results of the research and the implications of the research above, some suggestions that the researchers can address are as follows:

1. There needs to be an effort to increase the discipline of learning at the housekeeping lesson through increasing discipline study of students, increasing in-time admission, doing assignments and submitting on time.

2. There needs to be an effort to improve the learning outcomes of students' housekeeping through improving the learning environment that is good, fun and convenient for students to learn, whether it is in the family, school or family environment.

\section{References}

[1] J. Midwinter, "Something old, something new and something just in time: dilemmas for EE education and training," IEE Rev., vol. 46, no. 6, pp. 11-15, Nov. 2000.

[2] N. A. Wiyani, Manajemen pendidikan karakter: konsep dan implementasinya di sekolah. Yogyakarta: Pedagogia, 2012.

[3] A. Waller, "Special Session - Fish is Fish: Learning to See the Sea We Swim In: Theoretical Frameworks for Education Research," in Proceedings. Frontiers in Education. 36th Annual Conference, 2006, pp. 1-2.

[4] H. Ping and Y. Liu, "Demonstrative Analysis of Undergraduate Hospitality Management Education in Research-oriented Universities of China and of America," in 2010 Second International Workshop on Education Technology and Computer Science, 2010, vol. 1, pp. 735-738.

[5] M. De Lauretis, J. Ekman, and G. Antonini, "Delayed-rational Green's-function-based method of transmission lines and the Heaviside condition," in 2016 IEEE Electrical Design of Advanced Packaging and Systems (EDAPS), 2016, pp. 143-145.

[6] B. Lennartsson and E. Sundin, "Experience from a course aiming at understanding system development with focus on system design and integration," in 32nd Annual Frontiers in Education, 2002, vol. 1, p. T3G-1-T3G-6.

[7] S. Hassoun and G. Janssen, "First cadathlon programming contest held at 2002 ICCAD," IEEE Des. Test Comput., vol. 20, no. 3, pp. 104-107, May 2003.

[8] B. Herawan Hayadi, A. Bastian, K. Rukun, N. Jalinus, Y. Lizar, and A. Guci, "Expert System in the Application of Learning Models with Forward Chaining Method," Int. J. Eng. Technol., vol. 7, no. 2.29, p. 845, May 2018.

[9] D. Puyada, G. Ganefri, A. Ambiyar, R. E. Wulansari, and B. Herawan Hayadi, "Effectiveness of interactive instructional media on Electrical Circuits," Int. J. Eng. Technol., vol. 7, no. 2.14 Special Issue 14, 2018.

[10] Xue-song Yang and Yan Zhang, "PERT in product design application," in 2008 9th International Conference on Computer-Aided Industrial Design and Conceptual Design, 2008, pp. 283-287.

[11] Ximing Zhang, Suihuai Yu, and Jiaxing Liu, "Research on collaborative platform for industrial design based on PLM," in 2009 IEEE 10th International Conference on Computer-Aided Industrial Design \& Conceptual Design, 2009, pp. 1165-1169. 